\title{
Proteomics Reveals Octyl Gallate as an Environmentally Friendly Wood Preservative Leading to Reactive Oxygen Species-Driven Metabolic Inflexibility and Growth Inhibition in White-Rot Fungi (Lenzites betulina and Trametes versicolor)
}

\author{
Jin-Wei Xu ${ }^{1}{ }^{D}$, Chen-Chung Liao ${ }^{2}$, Ke-Chang Hung ${ }^{1}$, Zhong-Yao Wang ${ }^{1}$, Yu-Tang Tung ${ }^{3, *}$ and Jyh-Horng Wu ${ }^{1, *(D)}$ \\ 1 Department of Forestry, National Chung Hsing University, Taichung 40227, Taiwan; \\ ecsgunro@gmail.com (J.-W.X.); d9833004@mail.nchu.edu.tw (K.-C.H.); hi4u2ca707@gmail.com (Z.-Y.W.) \\ 2 Proteomics Research Center, National Yang-Ming University, Taipei 11221, Taiwan; ccliao@ym.edu.tw \\ 3 Graduate Institute of Biotechnology, National Chung Hsing University, Taichung 40227, Taiwan \\ * Correspondence: peggytung@nchu.edu.tw (Y.-T.T.); eric@nchu.edu.tw (J.-H.W.)
}

check for updates

Citation: $\mathrm{Xu}$, J.-W.; Liao, C.-C.; Hung, K.-C.; Wang, Z.-Y.; Tung, Y.-T.; Wu, J.-H. Proteomics Reveals Octyl Gallate as an Environmentally Friendly Wood Preservative Leading to Reactive Oxygen Species-Driven Metabolic Inflexibility and Growth Inhibition in White-Rot Fungi (Lenzites betulina and Trametes versicolor). J. Fungi 2021, 7, 145. https://doi.org/10.3390/jof7020145

Received: 1 February 2021

Accepted: 13 February 2021

Published: 17 February 2021

Publisher's Note: MDPI stays neutral with regard to jurisdictional claims in published maps and institutional affiliations.

Copyright: (c) 2021 by the authors. Licensee MDPI, Basel, Switzerland. This article is an open access article distributed under the terms and conditions of the Creative Commons Attribution (CC BY) license (https:// creativecommons.org/licenses/by/ $4.0 /)$.
Abstract: The most commonly applied wood preservatives are based on creosote, pentachlorophenol, and waterborne chromate copper arsenate, which negatively affect the environment. Thus, environmentally friendly wood preservatives are required. This study investigated the antifungal activity and mechanism of several long-chain alkyl gallates (3,4,5-trihydroxybenzoates) against white-rot fungi, Lenzites betulina and Trametes versicolor. The results revealed that octyl gallate (OG) had the best antifungal activity. Additionally, OG may have a mechanism of action similar to surfactants and inhibit ATPase activity, causing mitochondrial dysfunction and endogenous reactive oxygen species (ROS) production. Upon exposure to endogenous ROS, cells rapidly inhibit the synthesis of 605 ribosomal subunits, thus reducing the mycelial growth rate. L. betulina and T. versicolor also remodeled their energy metabolism in response to low ATP levels and endogenous ROS. After OG treatment, ATP citrate synthase activity was downregulated and glycolytic activity was upregulated in L. betulina. However, the activity of aerobic pathways was decreased and the oxidative branch of the pentose phosphate pathway was redirected form nicotinamide adenine dinucleotide phosphate (NADPH) to minimize endogenous ROS-mediated damage in T. versicolor. Taken together, these observations reveal that OG is a potent inhibitor of white-rot fungus. Further structural optimization research and pharmacological investigations are warranted.

Keywords: antifungal activity; white-rot fungus; octyl gallate; proteomics; mitochondrial dysfunction; wood preservative

\section{Introduction}

Wood is widely used for architecture, decoration, and furniture because it is inexpensive and renewable and has low density, high impact strength, and low thermal conduction. However, wood is easily damaged by various biodeteriogens, such as fungi, bacteria, termites, insects, and marine microorganisms [1]. In general, wood degradation causes a loss of billions of dollars (USD) every year to repair and replace the damaged wood structures [2]. To prolong its lifespan, wood is commonly treated with preservatives to achieve protection against a broad range of biodeteriogens. The most commonly applied wood preservatives are creosote, pentachlorophenol, and waterborne chromate copper arsenate (CCA), because of their high degree of toxicity to fungi and insects [3,4]. However, they have negative effects on the environment. The chromium and arsenic leaching from CCA are known to be potent carcinogens. Therefore, CCA has been withdrawn from residential applications. Research has focused on environmentally friendly preservatives, and many extractives and agricultural waste products have been identified as potential inhibitors of wood degradation, including linseed and tung oil, tannins, stilbenes, methanolic extractives 
of beech wound-wood, pyrolysis distillates, and spent coffee grounds [5]. Among them, extractives and tannins with antifungal and insecticidal properties have attracted the most attention [6].

In many tannins, octyl gallate (OG) not only exerts diverse biological effects besides its antioxidant activity such as antibacterial, antifungal, antiviral, antidiabetic, antiamyloidogenic, and anticancer effects [7], but also exhibits activity against wood-decay fungi such as Lenzites betulina, Trametes versicolor, and Gloeophyllum trabeum [8]. Adding gallate derivatives to biocide reduces its inhibitory concentration values 2-256 times [9]. Gallate derivatives are also found in many phytomedicines. They have diverse biological and pharmacological activities, including free radical scavenging, maintenance of endogenous defense systems, metal ion chelation, inhibition of cell signaling pathways, and cancer cell apoptosis [10]. They may exert antifungal activity by disrupting the native membrane-associated function of the integral proteins as nonionic surfactants rather than common antioxidants $[11,12]$. However, specific studies on their antifungal activity against basidiomycete white-rot fungi are limited. Moreover, the role of hydrophobic alkyl chain length on gallate derivatives remains poorly understood. Therefore, this study investigated the antifungal activity of a series of long-chain alkyl gallates (3,4,5-trihydroxybenzoates) against the most common and worldwide distributed white-rot fungi (L. betulina and T. versicolor) using the agar dilution method. Additionally, laccase and manganese peroxidase $(\mathrm{MnP})$ assays and proteomics analysis were conducted to identify changes in L. betulina and T. versicolor in response to the addition of OG.

\section{Materials and Methods}

\subsection{Chemicals and Fungal Strain}

Gallic acid, methyl gallate (MG), ethyl gallate (EG), butyl gallate (BG), OG, decyl gallate (DG), and hexadecyl gallate (HG) were purchased from Tokyo Kasei Kogyo (Tokyo, Japan). The other chemicals and solvents used in this experiment were purchased from Merck (Darmstadt, Germany). The white-rot fungi L. betulina (Fries) (BCRC35296) and T. versicolor (Linnaeus: Fries) (BCRC35253) were obtained from the Bioresource Collection and Research Center of Food Industry Research and Development Institute in Taiwan.

\subsection{Antifungal Assays}

The agar dilution method was used to evaluate the antifungal activity of long-chain alkyl gallates following the method reported by Hsu et al. [7]. The long-chain alkyl gallates were dissolved in $15 \mu \mathrm{L}$ of methanol, which was added to $5 \mathrm{~mL}$ of sterilized potato dextrose agar solution (PDA, $39 \mathrm{~g} / \mathrm{L}$ ) in a 6-cm petri dish. After the solidification of the media, L. betulina and T. versicolor plugs ( $3 \mathrm{mM}$ in diameter) were placed on PDA media, and the petri dish was sealed with parafilm and incubated at $27 \pm 2{ }^{\circ} \mathrm{C}$ and $70 \%$ relative humidity $(\mathrm{RH})$. When the mycelia reached the edges of control plates (methanol was used as the control), antifungal assays were performed. The antifungal index (\%) was calculated as follows: $(1-\mathrm{D} t / \mathrm{D} c) \times 100$, where $\mathrm{D} t$ and $\mathrm{D} c$ are growth zone diameters $(\mathrm{cm})$ in the experimental and control plates, respectively.

Submerged cultivation was used to evaluate antifungal and enzyme activities following the method reported by Kubo et al. [11] with slight modifications. The OG was dissolved in $1 \mathrm{~mL}$ of methanol, which was added to $150 \mathrm{~mL}$ of sterilized malt extract solution $(17 \mathrm{~g} / \mathrm{L})$ in a $250-\mathrm{mL}$ flask. When the media returned to $27^{\circ} \mathrm{C}$, a mycelial plug ( $3 \mathrm{mM}$ in diameter) was placed on the media. The flask was sealed with parafilm and incubated at $150 \mathrm{rpm}, 27 \pm 2{ }^{\circ} \mathrm{C}$, and $70 \% \mathrm{RH}$. In brief, incubation times of 9 and 7 days for L. betulina and T. versicolor, respectively, were selected when the weight of growing mycelia reached $50 \mathrm{mg}$. When mycelia reached $50 \mathrm{mg}$ in weight in the control flask (methanol was used as the control), the weight of mycelium and the $\mathrm{pH}$ of the filtrate were recorded. Antifungal assays were performed three times. The antifungal index (\%) was calculated as $(1-\mathrm{W} t / \mathrm{Wc}) \times 100$, where $\mathrm{W} t$ and $\mathrm{Wc}$ represent the weight $(\mathrm{mg})$ of mycelia in the experimental and control flasks, respectively. 


\subsection{1,1-Diphenyl-2-Picrylhydrazyl Assay}

The 1,1-diphenyl-2-picrylhydrazyl (DPPH) radical-scavenging activity of long-chain alkyl gallates was examined according to the method reported by Lin et al. [13]. In brief, $10 \mu \mathrm{L}$ of compounds in DMSO (final concentrations of $1,5,10,25,50$, and $100 \mu \mathrm{g} / \mathrm{mL}$ ) were mixed with $90 \mu \mathrm{L}$ of $50 \mathrm{mM}$ Tris-HCl buffer (pH 7.4) and $200 \mu \mathrm{L}$ of a $0.1 \mathrm{mM}$ DPPH-ethanol solution. After $30 \mathrm{~min}$ of incubation at ambient temperature, the reduction in DPPH free radicals was determined according to the absorbance at $517 \mathrm{~nm}$, which was measured using the ELISA reader. (+)-Catechin was used as a positive control. Three replicates were made for each test sample. The inhibition ratio (\%) was calculated as $(1-\mathrm{A} t / \mathrm{Ac}) \times 100$, where $\mathrm{A} t$ is the absorbance of the experimental reaction and $\mathrm{A} c$ is the absorbance of the control reaction.

\subsection{Ferrous Ion-Chelating Ability Assay}

The ferrous ion-chelating potential of long-chain alkyl gallates was evaluated following the method reported by Lin et al. [13]. In brief, $200 \mu \mathrm{L}$ of a series of long-chain alkyl gallates in methanol (final concentrations of $0.1,0.2,0.5,1,2,5,10,20,50,100,200,500$, and $1000 \mu \mathrm{g} / \mathrm{mL}$ ) and $740 \mu \mathrm{L}$ of methanol were added to $20 \mu \mathrm{L}$ of $2 \mathrm{mM} \mathrm{FeCl}_{2}$. The reaction was initiated through the addition of $40 \mu \mathrm{L}$ of $5 \mathrm{mM}$ ferrozine. The mixture was shaken vigorously and allowed to rest at ambient temperature for $10 \mathrm{~min}$. Absorbance of the solution was measured at $562 \mathrm{~nm}$. Ethylenediaminetetraacetic acid (EDTA) was used as a positive control. Three replicates were made for each test sample. The percentage of inhibition of the ferrozine- $\mathrm{Fe}^{2+}$ complex formation was calculated as $(1-\mathrm{A} t / \mathrm{A} c) \times 100$, where $\mathrm{A} t$ is the absorbance of the experimental reaction and $\mathrm{A} c$ is the absorbance of the control reaction.

\subsection{Determination of Laccase and Manganese Peroxidase Activities}

This assay was determined according to the method described by Tamagawa et al. [14]. The laccase activity was determined through monitoring of the oxidation of 2,6dimethoxyphenol (DMP) at $470 \mathrm{~nm}$ and $30^{\circ} \mathrm{C}$. The solution $(300 \mu \mathrm{L})$ was mixed with $1 \mathrm{mM}$ DMP and $50 \mathrm{mM}$ malonate buffer ( $\mathrm{pH}$ 4.5). The manganese peroxidase (MnP) activity was determined in the same manner, except that the reaction mixture also contained $0.1 \mathrm{mM} \mathrm{MnSO}_{4}$ and $0.2 \mathrm{mM} \mathrm{H}_{2} \mathrm{O}_{2}$.

\subsection{Protein Sample Preparation}

Each mycelium sample from submerged cultivation was placed in a $1.5-\mathrm{mL}$ sample tube that contained $0.2 \mathrm{~g}$ of ceramic beads $(0.5 \mathrm{mM}$ in diameter), $5 \mu \mathrm{L}$ of phenylmethylsulfonyl fluoride, and $0.25 \mathrm{~mL}$ of breaking buffer ( $0.69 \mathrm{~g}$ of sodium phosphate, $0.037 \mathrm{~g}$ of EDTA, $5 \mathrm{~mL}$ of glycerol, and $90 \mathrm{~mL}$ of deuterium-depleted water). Tissue debris was removed through centrifugation at $12,000 \times g$ for $10 \mathrm{~min}$ at $4{ }^{\circ} \mathrm{C}$, and the supernatant was transferred to a new Eppendorf tube. The protein concentration was measured using a bicinchoninic acid protein assay kit (Thermo, Rockford, IL, USA).

\subsection{SDS-PAGE}

Mycelium protein samples were fractionated by $12 \%$ SDS-PAGE (Hoefer ${ }^{\circledR}$, Holliston, MA, USA) according to the method described by Liao et al. [15]. In brief, $50 \mu \mathrm{g}$ of each protein sample was applied to the gel in triplicate, and the sizes of proteins were visualized through staining with Coomassie Brilliant Blue. The gel lanes were split into 10 equal fractions, and the slices were destained through repeat washing in a solution of $25 \mathrm{mM}$ ammonium bicarbonate and 50\% $(v / v)$ acetonitrile (1:1) until the protein bands were invisible. The resulting gel was dried in a SpeedVac and stored at $-20^{\circ} \mathrm{C}$.

\subsection{Nanoflow Ultra-High-Performance Liquid Chromatography-Tandem Mass Spectrometry}

Each cryostored tryptic digest was resuspended in $30 \mu \mathrm{L}$ of $0.1 \%(v / v)$ formic acid and analyzed using an online nanoAcquity ultra-performance liquid chromatography 
(UPLC) system (Waters, Manchester, UK) coupled to a hybrid linear ion trap Orbitrap (LTQ-Orbitrap Discovery) mass spectrometer with a nanoelectrospray ionization source (Thermo Scientific, San Jose, CA, USA). After the sample was loaded with a single injection model into the UPLC, the peptides were captured and desalted on a C18 trap column $(180 \mu \mathrm{m} \times 20 \mathrm{mM}$; Waters, MA, USA $)$ and then further separated using a BEH C18 column $(25 \mathrm{~cm} \times 75 \mu \mathrm{m}$; Waters, MA, USA). Mobile phase solvents A and B were prepared as $0.1 \%$ formic acid in water and $0.1 \%$ formic acid in acetonitrile, respectively. The separation condition was achieved through elution of the peptides from the column with a linear gradient of $5-35 \%$ A/B for $90 \mathrm{~min}, 35-95 \%$ A/B for $2 \mathrm{~min}$, and $95 \%$ A/B for $10 \mathrm{~min}$ at a flow rate of $0.5 \mu \mathrm{L} / \mathrm{min}$. The eluted peptides were ionized with a spray voltage of $2.33 \mathrm{kV}$ and introduced into the mass spectrometer. Mass spectrometric data were obtained using a data-dependent acquisition method (isolation width: $2 \mathrm{Da}$ ) in which one full MS survey scan (m/z: 200-1500) at a high resolution of 30,000 full at half maximum width was followed by tandem mass spectrometry (MS/MS) scanning (m/z: 200-1500) of the six most intense multiply charged ions $\left(2^{+}\right.$and $\left.3^{+}\right)$. Fragment ions of each selected precursor were generated through collision-induced dissociation using helium gas with collision energy of $35 \%$ (or $3.5 \mathrm{eV}$ ). The dynamic exclusion duration of precursors was set to $120 \mathrm{~s}$ with an exclusion list size of 200.

\subsection{Mass Spectrometric Data Analysis}

Liquid chromatography-MS/MS raw data were analyzed with Peaks 7.5 Studio software for proteomics (Bioinformatics Solutions, Waterloo, Canada). The search was conducted against the UniProt database (containing 1,715,780 protein sequences; released on January 2020; http:/ / www.uniprot.org/; accessed on 29 September 2020). The search parameters were as follows: parent mass error tolerance, $50 \mathrm{ppm}$; fragment mass error tolerance, $0.8 \mathrm{Da}$; enzyme set as trypsin; and two missed cleavages allowed, with oxidation on methionine $(+15.99 \mathrm{Da})$ and carbamidomethylation on cysteine $(+57.02 \mathrm{Da})$ used as variable modifications. The average local confidence was established at $>80 \%$. A decoy database was used to calculate the false discovery rate, which was set to $<1 \%$. A protein was identified when at least one unique peptide was matched. Protein quantitative analysis using MS spectra counting involved the use of in-house software [16,17].

\subsection{Statistical Analysis}

All results were expressed as the mean \pm standard deviation. The significance of differences was calculated using Scheffe's test, and values of $<0.05$ were considered to be significant. This method made all pairwise comparisons between the means and was a very reliable procedure that violated the assumptions associated with ANOVA.

\section{Results and Discussion}

\subsection{Antifungal Activity of Long-Chain Alkyl Gallates}

An agar dilution test was performed to assess the antifungal activity of long-chain alkyl gallates against $100 \mu \mathrm{g} / \mathrm{mL}$ of L. betulina and T. versicolor. The antifungal indexes of gallic acid, MG, EG, BG, OG, DG, and HG were $13.4 \%, 29.9 \%, 28.6 \%, 44.9 \%, 66.4 \%$, $45.6 \%$, and $45.2 \%$, respectively, against L. betulina and $0 \%, 0 \%, 5.4 \%, 38.6 \%, 50.3 \%, 40.6 \%$, and $40.1 \%$, respectively, against T. versicolor (Figure 1). Among them, OG had the best antifungal activity. Notably, the half maximal effective concentration $\left(\mathrm{EC}_{50}\right)$ values of $\mathrm{OG}$ which were calculated by linear interpolation were 74.7 and $95.8 \mu \mathrm{g} / \mathrm{mL}$ against $L$. betulina and T. versicolor, respectively. This result indicated that the activity of gallates increased with the increase in alkyl chain length, reaching a maximum with OG, and then decreased as the chain length increased. 


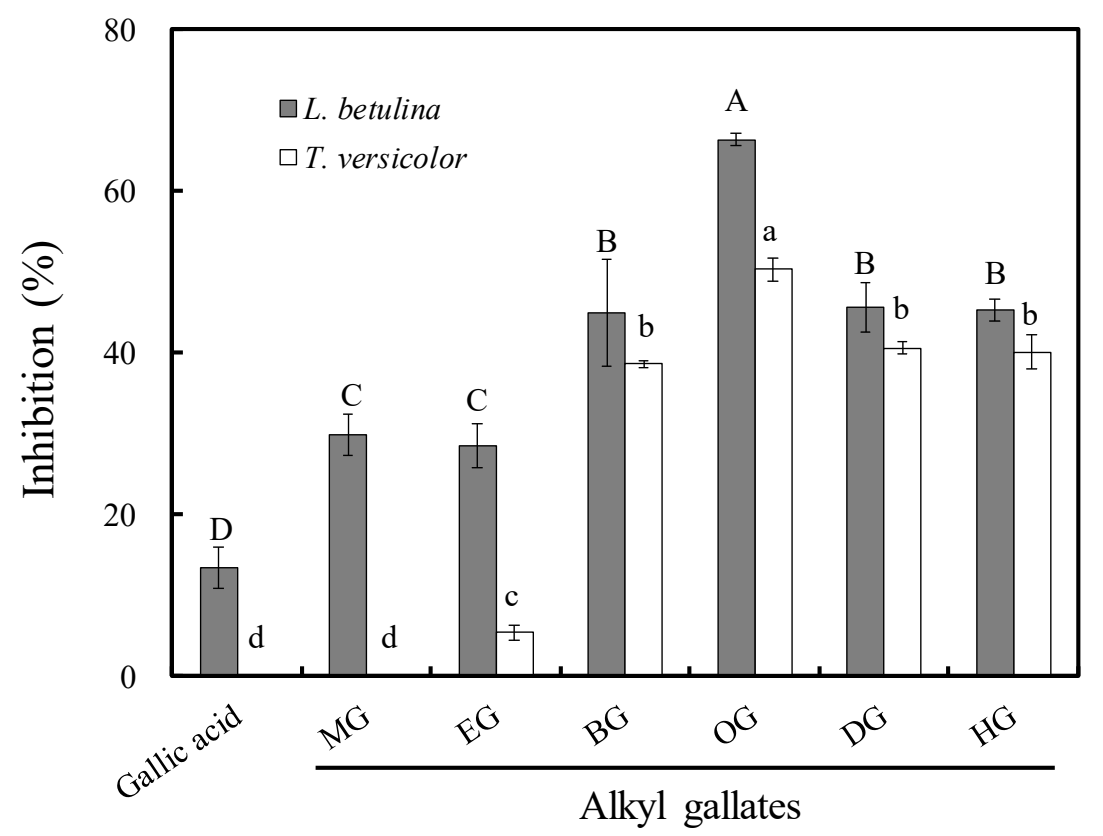

Figure 1. Effects of the alkyl chain length of gallates and gallic acid on antifungal activity against L. betulina and T. versicolor at the concentration of $100 \mu \mathrm{g} / \mathrm{mL}$. MG: methyl gallate, EG: ethyl gallate, BG: butyl gallate, OG: octyl gallate, DG: decyl gallate, and HG: hexadecyl gallate. Values are expressed as the mean \pm standard deviation $(n=3)$. Each bar with different letters is significantly different at $p<0.05$.

\subsection{Antioxidant Activity and Ferrous Ion-Chelating Effect of Long-Chain Alkyl Gallates}

The free radical-scavenging activity of the tested gallates was assessed using DPPH assay. As shown in Figure 2, all gallates showed strong DPPH radical-scavenging activity. The $\mathrm{EC}_{50}$ values of long-chain alkyl gallates slightly decreased with the increased chain length, possibly because gallates with more alkyl chains had a smaller proportion of pyrogallol moiety, leading to a reduction in antioxidant activity [7].

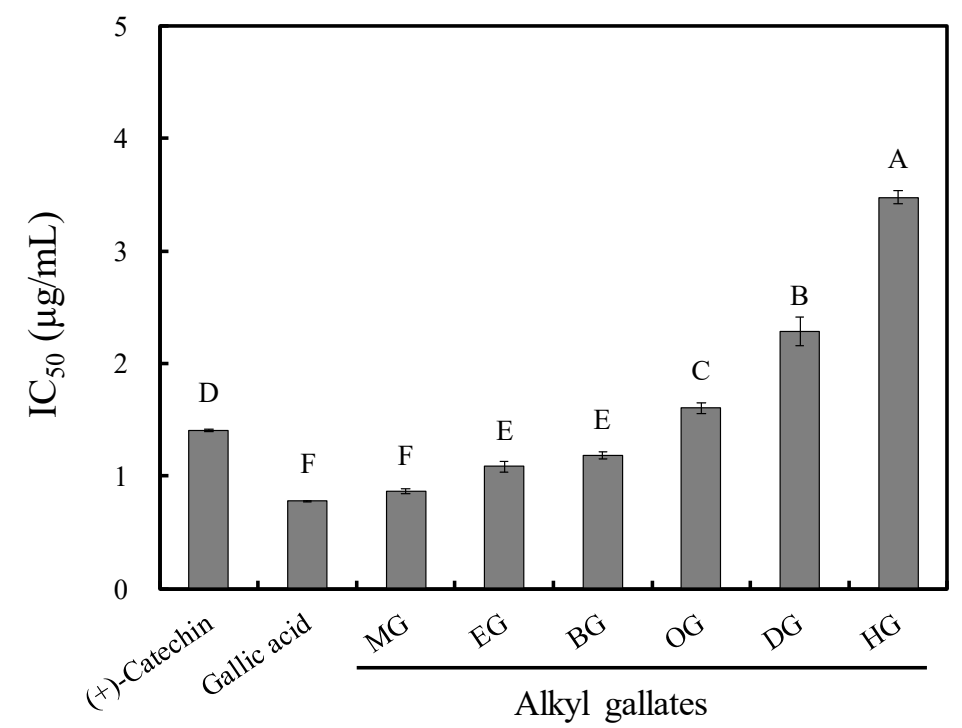

Figure 2. Effects of the alkyl chain length of gallates and gallic acid on DPPH radical-scavenging activity. MG: methyl gallate, EG: ethyl gallate, BG: butyl gallate, OG: octyl gallate, DG: decyl gallate, and HG: hexadecyl gallate. Values are expressed as the mean \pm standard deviation $(n=3)$. Each bar with different letters is significantly different at $p<0.05$. 
Additionally, the ferrous ion-chelating activity of long-chain alkyl gallates is shown in Figure 3. Although the chelating ability of EDTA increased with the concentration, the long-chain alkyl gallates did not demonstrate any chelating ability. This result may be because the galloyl group was less capable of chelating iron and reduced iron binding [18]. However, when the free radical-scavenging and ferrous ion-chelating activities of longchain alkyl gallates were compared with their antifungal activity, the results indicated that their action against white-rot fungi might not be completely related to their antioxidant activity or iron-binding capacity.

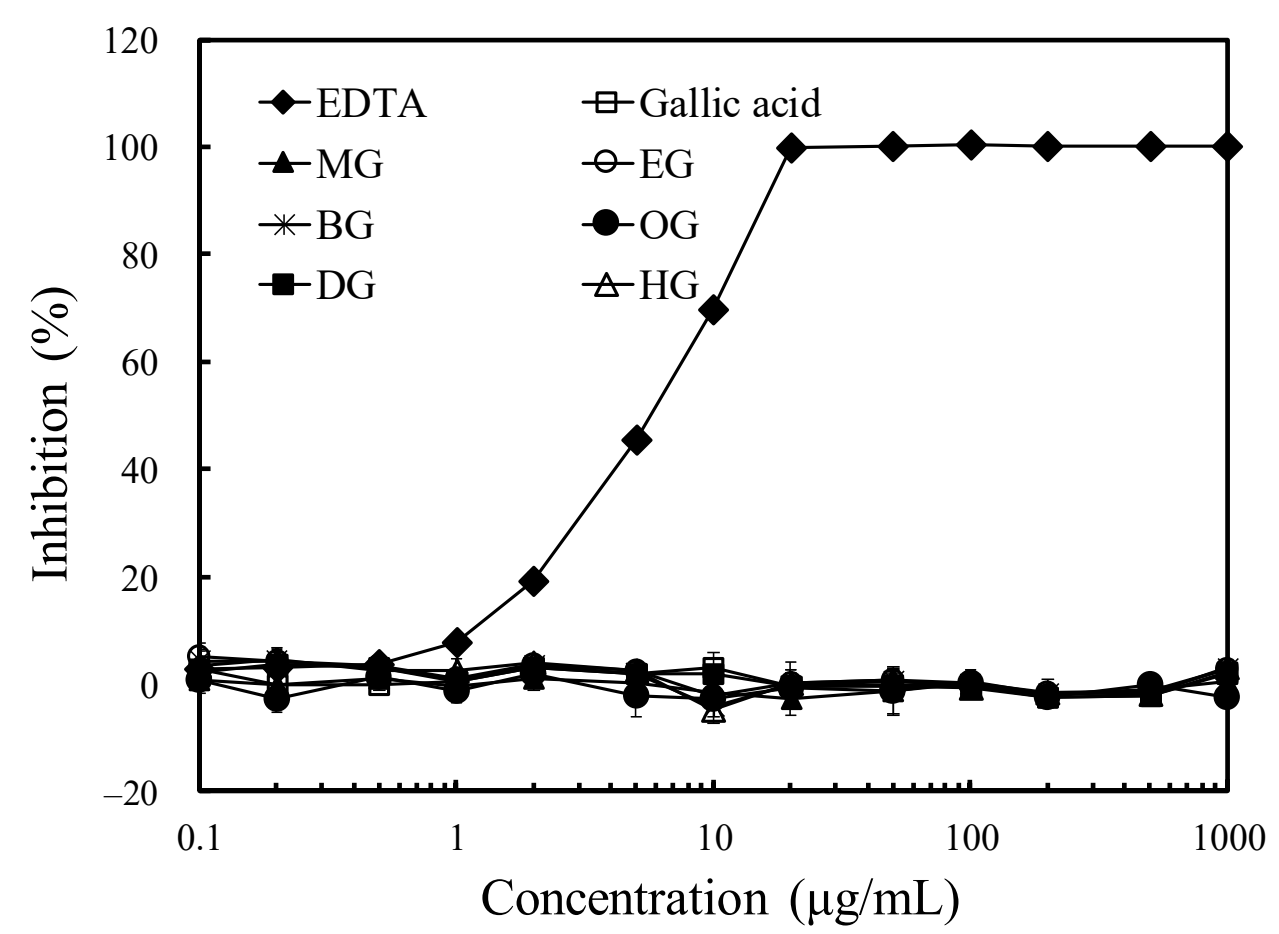

Figure 3. Effects of the alkyl chain length of gallates and gallic acid on ferrous ion-chelating ability. MG: methyl gallate, EG: ethyl gallate, BG: butyl gallate, OG: octyl gallate, DG: decyl gallate, and HG: hexadecyl gallate. Values are expressed as the mean \pm standard deviation $(n=3)$.

\subsection{Effects of OG on the Laccase and Manganese Peroxidase Activities of L. betulina and T. versicolor}

Among the gallate derivatives, OG had the best antifungal activity. Therefore, the further study of laccase and $\mathrm{MnP}$ were concentrated in OG. OG also inhibited fungal growth in the submerged cultivation test. As shown in Figure $4 \mathrm{~A}, \mathrm{~B}$, the antifungal indexes of OG against L. betulina at concentrations of $2.5,5,10,15$, and $20 \mu \mathrm{g} / \mathrm{mL}$ were $33.1 \%$, $58.7 \%, 68.4 \%, 92.1 \%$, and $99.9 \%$, respectively, and against $T$. versicolor at concentrations of $5,10,15,20$, and $25 \mu \mathrm{g} / \mathrm{mL}$ were $27.3 \%, 51.3 \%, 86.6 \%, 91.8 \%$, and $95.9 \%$, respectively. However, the medium acidification exhibited no significant difference compared with the addition of OG (Figure 4A,B). To understand the effect of OG on laccase and $\mathrm{MnP}$ activities, the $\mathrm{EC}_{50}$ values (4.2 and $9.7 \mu \mathrm{g} / \mathrm{mL}$ against L. betulina and T. versicolor, respectively) of OG were selected for further study. 

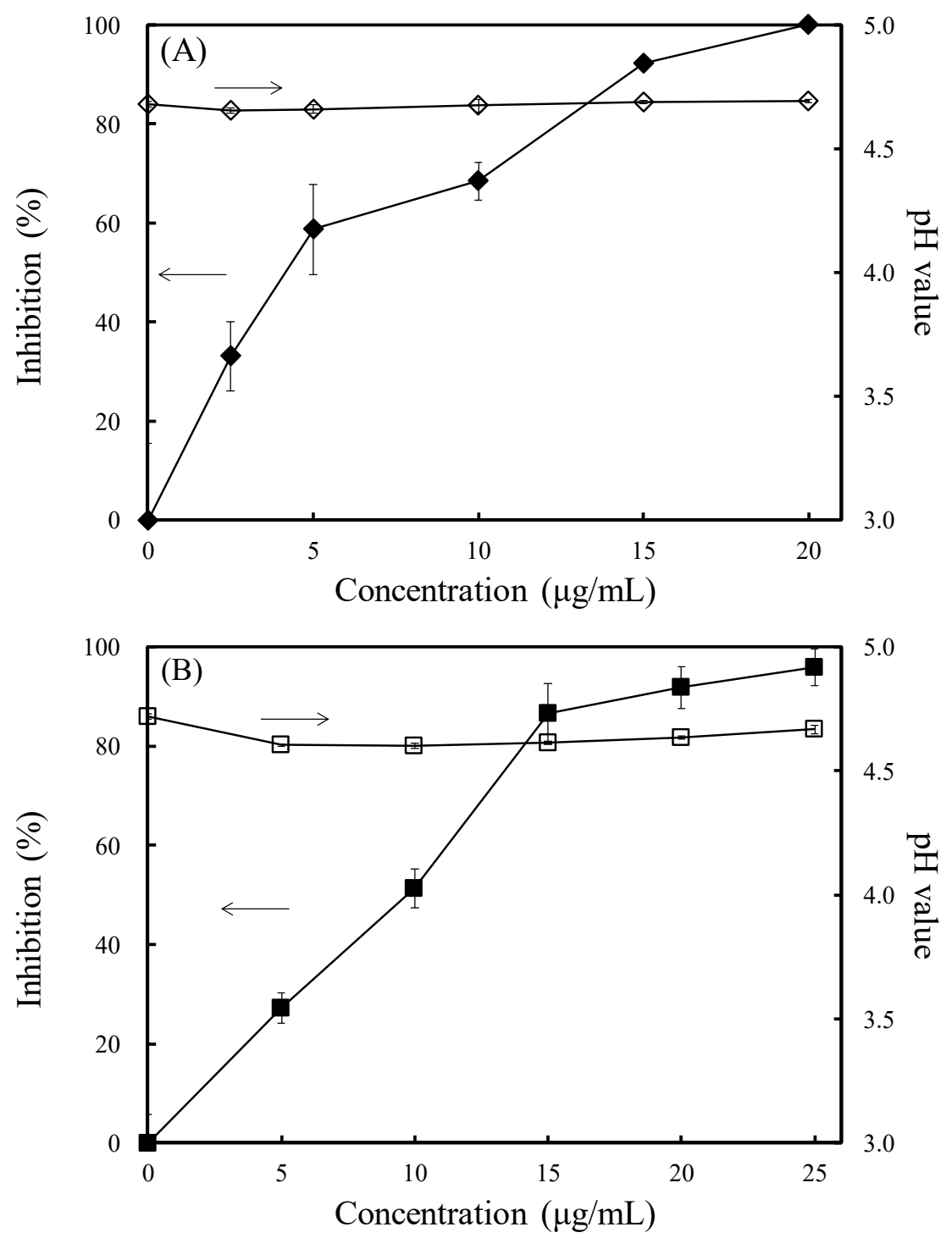

Figure 4. Effects of octyl gallate (OG) on the inhibition and medium acidification of L. betulina (A) and T. versicolor $(\mathbf{B})$. Values are expressed as the mean \pm standard deviation $(n=3)$. The arrows indicate the $y$-axis relative to the arrowed lines.

Figure 5 presents the laccase and MnP activities of L. betulina and T. versicolor. The rate and extent of laccase and $\mathrm{MnP}$ activities of $T$. versicolor were significantly higher than those of L. betulina, consistent with the reports of Sergentani et al. [19] and Alberts et al. [20]. Additionally, as shown in Figure 5A,B, neither enzyme of L. betulina was expressed when OG was added, consistent with the result reported by Tortella et al. [21]. By contrast, both enzymes of $T$. versicolor were significantly upregulated with the addition of OG, which may accelerate wood decay. This can be mainly attributed to laccase induction, which may play a defensive role through the catalyzation of polymerization or generation of oxidative stress by toxic aromatic compounds structurally related to lignin derivatives [22]. Additionally, the very close cooperation between superoxide dismutase and laccase may produce reactive oxygen species (ROS), which are fully involved in white-rot fungi-induced biodegradation [23]. Thus, OG may be different from typical antifungal agents, which exert their antifungal action through free radical scavenging, metal chelation, or enzyme inhibition. Its antifungal mechanisms may be worth studying. Proteomics is a powerful tool for studying changes in protein expression for pathogenic processes. Therefore, we performed proteomics analysis to identify the response of L. betulina and T. versicolor to the addition of OG. 


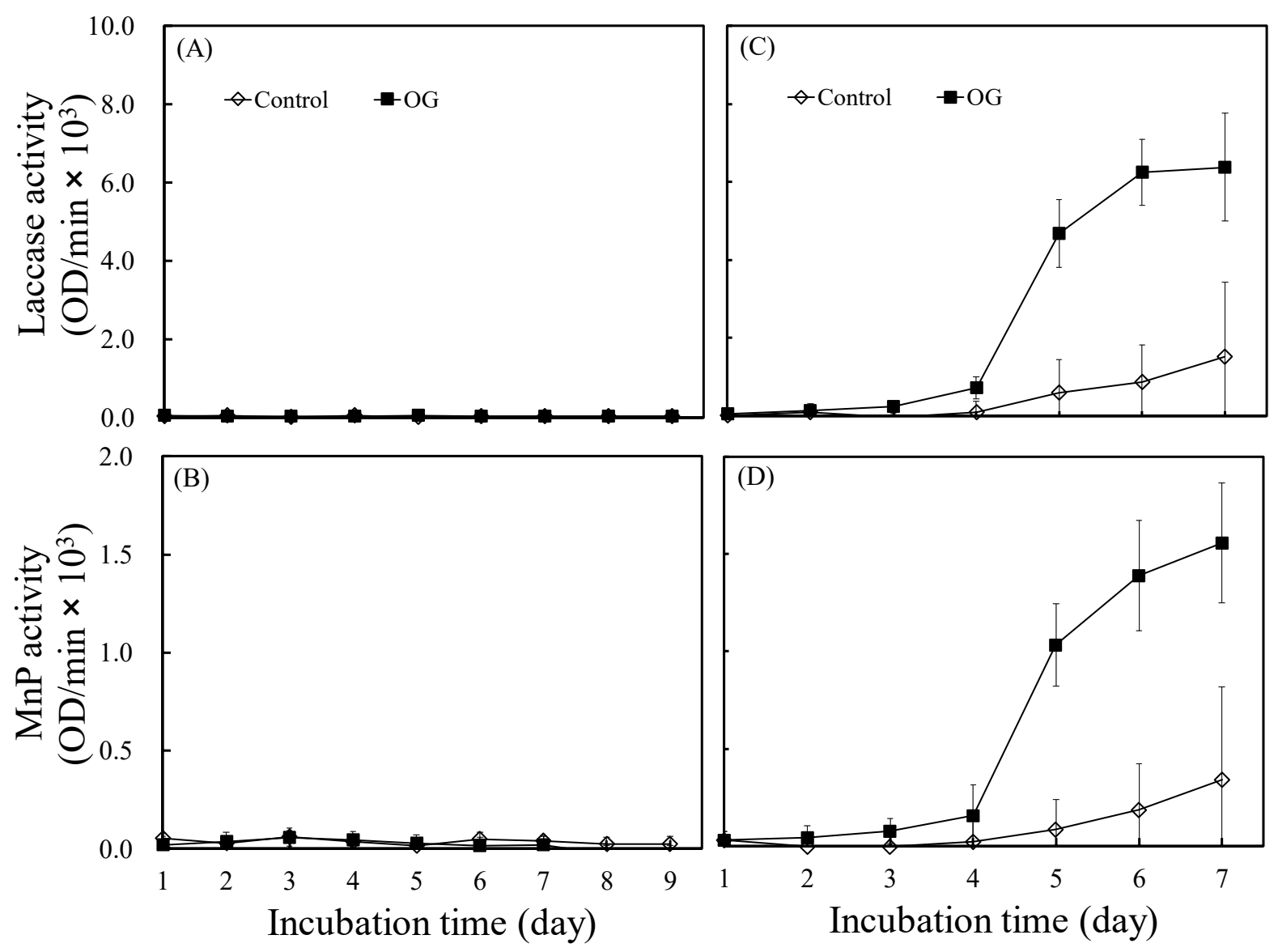

Figure 5. Effects of octyl gallate $(\mathrm{OG})$ on the laccase and manganese peroxidase $(\mathrm{MnP})$ activities of L. betulina at the concentration of $4 \mu \mathrm{g} / \mathrm{mL}$ (A and $\mathbf{B}$, respectively) and T. versicolor at the concentration of $10 \mu \mathrm{g} / \mathrm{mL}$ (C and D, respectively). Values are expressed as the mean \pm standard deviation $(n=3)$.

\subsection{Proteomics Analysis}

The mycelial proteins were separated through electrophoresis and analyzed using MS/MS. The spectra generated were analyzed with Peaks 7.5 studio to identify the peptide sequences queried against the UniProt database. Next, a 2931 protein sequence was obtained, with 25 (Tables 1 and 2) and 53 (Tables 3 and 4) proteins that were considerably different before and after OG treatment in L. betulina and T. versicolor, respectively. As shown in Figure 6, OG treatment downregulated L. betulina proteins related to ATP binding, cofactor binding, the structural constituent of ribosome, and translation and upregulated those related to double-stranded DNA binding, ketol-acid reductoisomerase activity, triose-phosphate isomerase activity, gluconeogenesis, mitochondrial genome maintenance, pentose phosphate shunts, and the glycolytic, isoleucine biosynthetic, and valine biosynthetic processes.

Table 1. Proteins of Lenzites betulina that were upregulated due to the addition of octyl gallate.

\begin{tabular}{|c|c|c|c|c|c|}
\hline Protein Name & Accession No. & pI & MW & GO & Expression Ratio \\
\hline $\begin{array}{c}\text { 60S ribosomal protein L9-B } \\
\text { (Schizosaccharomyces pombe } 972 \mathrm{~h}-\text { ) }\end{array}$ & A0A0K6FS64_9HOMO & 9.38 & $21,383.81$ & - & 3.92 \\
\hline $\begin{array}{c}\text { Ketol-acid reductoisomerase, } \\
\text { mitochondrial }\end{array}$ & W4KC19_9HOMO & 8.85 & $44,553.29$ & - & 2.17 \\
\hline $\begin{array}{l}\text { Ketol-acid reductoisomerase, } \\
\text { mitochondrial }\end{array}$ & A0A0C3DUH5_9HOMO & 8.91 & $44,841.78$ & - & 2.04 \\
\hline
\end{tabular}


Table 1. Cont.

\begin{tabular}{cccccc}
\hline Protein Name & Accession No. & pI & MW & GO & Expression Ratio \\
\hline $\begin{array}{c}\text { Ketol-acid reductoisomerase, } \\
\text { mitochondrial }\end{array}$ & A0A060SWV9_PYCCI & 8.98 & $44,706.68$ & - & 1.98 \\
\hline Triosephosphate isomerase & R4I570_9AGAR & 5.70 & $26,921.71$ & - & 3.89 \\
\hline Triosephosphate isomerase & A0A0C3PQJ3_PHLGI & 5.50 & $26,627.37$ & - & 3.46 \\
\hline Triosephosphate isomerase & A0A151V9C9_HYPMA & 5.97 & $26,765.62$ & - & - \\
\hline Triosephosphate isomerase & S8FUL8_FOMPI & 6.00 & $26,850.73$ & 3.46 \\
\hline Uncharacterized protein & A0A0C3S325_PHLGI & 11.17 & $20,963.75$ & 0006412 & 3.84 \\
\hline
\end{tabular}

pI: theoretical isoelectric point, MW: molecular weight, and GO: gene ontology.

Table 2. Proteins of Lenzites betulina that were downregulated due to the addition of octyl gallate.

\begin{tabular}{cccccc}
\hline Protein Name & Accession No. & pI & MW & GO & Expression Ratio \\
\hline 60S ribosomal protein L12 & A0A165F4X5_9APHY & 9.19 & $17,522.26$ & 0006412 & 0.09 \\
60S ribosomal protein L12 & A0A165RLF8_9APHY & 9.06 & $17,510.30$ & 0006412 & 0.09 \\
60S ribosomal protein L12 & A0A1C7LQZ3_GRIFR & 9.35 & $17,364.10$ & - & 0.09 \\
60S ribosomal protein L12 & B8P7S1_POSPM & 9.19 & $17,550.31$ & 0006412 & 0.09 \\
ATP citrate lyase isoform 2 & A0A0D7B0G9_9HOMO & 6.55 & $125,756.11$ & - & 0.11 \\
ATP citrate synthase & A0A165GIY9_9APHY & 8.33 & $125,805.87$ & - & Control only \\
GroES-like protein & A0A166C2Q9_9HOMO & 6.37 & $37,305.72$ & - & 0.25 \\
Heat shock protein 90 & R7S7P6_TRAVS & 4.95 & $79,624.25$ & 0006457 & 0.39 \\
Heat shock protein HSP 90-alpha & A0A0B7FTU3_THACB & 4.94 & $79,834.83$ & - & - \\
Mitochondrial glycoprotein & R7SPA0_DICSQ & 4.67 & $29,577.92$ & 0006950 & 0.36 \\
Uncharacterized protein & J4HUC5_9APHY & 9.59 & $37,362.90$ & 0006412 & 0.25 \\
Uncharacterized protein & M2R3S2_CERS8 & 9.06 & $17,655.46$ & 0006412 & 0.09 \\
Uncharacterized protein & A0A060S428_PYCCI & 7.63 & $107,357.17$ & - & 0.09 \\
Uncharacterized protein & A0A0C3P9N6_PHLGI & 9.32 & $17,499.22$ & 0006412 & 0.21 \\
Uncharacterized protein & K5UVC6_PHACS & 9.19 & $17,396.05$ & 0006412 & 0.09 \\
Uncharacterized protein & S8FGW3_FOMP & 9.06 & $17,496.28$ & 0006412 & 0.09 \\
\hline
\end{tabular}

pI: theoretical isoelectric point, MW: molecular weight, and GO: gene ontology.

Table 3. Proteins of Trametes versicolor that were upregulated due to the addition of octyl gallate.

\begin{tabular}{|c|c|c|c|c|c|}
\hline Protein Name & Accession No. & pI & MW & GO & Expression Ratio \\
\hline $40 S$ ribosomal protein & A0A146HFY9_9AGAR & 10.20 & $17,473.48$ & 0006412 & 4.99 \\
\hline $40 S$ ribosomal protein $\mathrm{S} 15$ & A0A0B7FZY5_THACB & 10.24 & $17,610.61$ & 0006412 & 3.78 \\
\hline $40 S$ ribosomal protein $\mathrm{S} 15$ & A0A151VTC7_HYPMA & 10.31 & $17,514.54$ & 0006412 & 3.78 \\
\hline $40 S$ ribosomal protein $S 15$ & L8X3B3_THACA & 9.90 & $16,454.27$ & 0006412 & 3.78 \\
\hline $\begin{array}{l}\text { 6-phosphogluconate dehydrogenase, } \\
\text { decarboxylating }\end{array}$ & A0A0C2X̄M62_AMAMU & 6.35 & $53,162.64$ & - & 2.43 \\
\hline $\begin{array}{l}\text { 6-phosphogluconate dehydrogenase, } \\
\text { decarboxylating }\end{array}$ & A0A0D7B7I4_9HOMO & 5.79 & $53,373.75$ & $\begin{array}{l}0019521 \\
0009051\end{array}$ & 3.72 \\
\hline $\begin{array}{l}\text { 6-phosphogluconate dehydrogenase, } \\
\text { decarboxylating }\end{array}$ & A0A146HJH8_9AGAR & 7.09 & $53,411.28$ & - & 2.37 \\
\hline ATP synthase subunit alpha & K5VTN2_PHACS & 9.15 & $58,843.66$ & 0015986 & 1.99 \\
\hline Chaperonin GroL & A0A165LVH4_9APHY & 5.79 & $62,855.91$ & - & 2.14 \\
\hline Heat shock protein & A8PB53_COPC7 & 5.62 & $63,344.06$ & - & 2.20 \\
\hline Uncharacterized protein & A0A060S4R5_PYCCI & 9.04 & $19,588.59$ & 0006412 & 2.84 \\
\hline Uncharacterized protein & A0A060SGS2_PYCCI & 9.74 & $13,299.48$ & 0006412 & 7.99 \\
\hline Uncharacterized protein & R7SX26_DICSQ & 10.51 & $17,474.38$ & - & 4.66 \\
\hline
\end{tabular}


Table 4. Proteins of Trametes versicolor that were downregulated due to the addition of octyl gallate.

\begin{tabular}{|c|c|c|c|c|c|}
\hline Protein Name & Accession No. & pI & MW & GO & Expression Ratio \\
\hline 605 ribosomal protein L3 & B8PIG2_POSPM & 10.26 & $4,3761.83$ & - & 0.45 \\
\hline $60 \mathrm{~S}$ ribosomal protein $\mathrm{L} 4 / \mathrm{L} 1 / \mathrm{L} 2$ & A0A165ZAV7_9HOMO & 11.12 & $40,412.82$ & 0006412 & 0.23 \\
\hline AAA ATPase & A0A165B9Y7_9APHY & 4.99 & $89,912.01$ & - & 0.46 \\
\hline Actin 1 & R7SI12_DICSQ & 5.44 & $41,692.58$ & - & 0.37 \\
\hline Actin-1 & A0A1C7LPB9_GRIFR & 5.35 & $42,816.81$ & - & 0.37 \\
\hline Adenosylhomocysteinase & M2QCQ6_CERS8 & 5.74 & $47,267.26$ & - & 0.42 \\
\hline Alanine-tRNA ligase & A0A060SL88_PYCCI & 5.75 & $106,172.69$ & - & 0.46 \\
\hline Beta-actin & V5W5W4_GANLU & 5.44 & $41,520.41$ & - & 0.37 \\
\hline Beta-actin-like protein & M2QI81_CERS8 & 5.44 & $41,692.58$ & - & 0.37 \\
\hline $\begin{array}{l}\text { Delta-1-pyrroline-5-carboxylate } \\
\text { dehydrogenase } 1\end{array}$ & A0A165ZHP2_9HOMO & 6.48 & $59,553.60$ & - & 0.32 \\
\hline Fructose 1,6-bisphosphate aldolase & A0A1B7N8B6_9HOMO & 6.02 & $38,850.08$ & - & Control only \\
\hline Glycerol dehydrogenase & R7S6H2_TRAVS & 5.30 & $42,121.11$ & - & 0.46 \\
\hline Glycerol dehydrogenase & R7SKI4_DICSQ & 5.58 & $40,618.43$ & - & 0.52 \\
\hline Heat shock cognate 70 & A0A0H2RYR8_9HOMO & 5.13 & $70,997.65$ & 1900035 & 0.45 \\
\hline Heat shock protein 70 & R7SN52_DICSQ & 5.64 & $71,837.59$ & - & 0.48 \\
\hline Malate dehydrogenase & A0A165P5J0_9HOMO & 6.45 & $33,510.44$ & $\begin{array}{l}0005975 \\
0006108 \\
0006099\end{array}$ & 0.31 \\
\hline Malate dehydrogenase & S7RXX1_GLOTA & 9.05 & $35,546.85$ & $\begin{array}{l}0005975 \\
0006108 \\
0006099\end{array}$ & 0.31 \\
\hline Phosphoglycerate kinase & A0A0C2XI58_AMAMU & 5.97 & $44,767.53$ & 0006096 & 0.16 \\
\hline Phosphoglycerate kinase & A0A0C3S5Q2_PHLGI & 5.99 & $44,470.21$ & 0006096 & 0.12 \\
\hline Phosphoglycerate kinase & A0A146IDB4_9AGAR & 6.15 & $44,134.66$ & - & Control only \\
\hline Putative carboxymethylenebutenolidase & A0A137QS07_9AGAR & 6.75 & $28,102.12$ & - & 0.33 \\
\hline $\begin{array}{l}\text { Related to HSP70 heat shock protein } 70 \\
\text { (Hsp70) }\end{array}$ & G4T8Z4_SERID & 5.14 & $70,572.25$ & $\begin{array}{l}0006515 \\
0006457 \\
0006616\end{array}$ & 0.42 \\
\hline Transaldolase & A0A060SMY4_PYCCI & 6.19 & $36,149.43$ & $\begin{array}{l}0005975 \\
0006098\end{array}$ & 0.35 \\
\hline Transaldolase & R7S6N3_TRAVS & 7.64 & $28,010.29$ & $\begin{array}{l}0005975 \\
0006098\end{array}$ & 0.42 \\
\hline Transketolase-like protein 2 & A0A1C7M6L6_GRIFR & 6.33 & $64,753.10$ & - & 0.15 \\
\hline Uncharacterized protein & A0A060S8Y5_PYCCI & 5.03 & $89,836.05$ & - & 0.52 \\
\hline Uncharacterized protein & J4G7W8_9APHY & 4.97 & $89,888.93$ & - & 0.48 \\
\hline Uncharacterized protein & J4GJQ5_9APHY & 5.56 & $72,198.74$ & - & 0.51 \\
\hline Uncharacterized protein & A0A060SCB9_PYCCI & 5.92 & $433,211.19$ & - & 0.35 \\
\hline Uncharacterized protein & A0A060SEM9_PYCC & 5.21 & $40,163.80$ & - & 0.45 \\
\hline Uncharacterized protein & A0A060SFD3_PYCCI & 5.13 & $70,262.90$ & $\begin{array}{l}0006515 \\
0006457 \\
0006616\end{array}$ & 0.44 \\
\hline
\end{tabular}


Table 4. Cont.

\begin{tabular}{cccccc}
\hline Protein Name & Accession No. & pI & MW & GO & Expression Ratio \\
\hline Uncharacterized protein & A0A060SNB2_PYCCI & 6.51 & $92,680.46$ & - & 0.34 \\
\hline Uncharacterized protein & A0A060SR94_PYCCI & 5.97 & $69,483.20$ & 0008152 & 0.27 \\
\hline Uncharacterized protein & A0A0C3NYK6_PHLGI & 5.37 & $41,591.47$ & - & - \\
\hline Uncharacterized protein & A0A0D2PLJ0_9AGAR & 6.31 & $30,884.26$ & -17 & 0.34 \\
\hline Uncharacterized protein & J4HZZ4_9APHY & 9.79 & $106,199.49$ & 0.46 \\
\hline Uncharacterized protein & S8ET35_FOMPI & 5.10 & $71,000.55$ & 1900035 & 0.46 \\
\hline $\begin{array}{c}\text { Unplaced genomic scaffold } \\
\text { CY34scaffold_2, whole genome } \\
\text { shotgun sequence }\end{array}$ & A0A0D0AGV4_9HOMO & 5.12 & $70,384.87$ & 0006515 & 0.37 \\
\end{tabular}

pI: theoretical isoelectric point, MW: molecular weight, and GO: gene ontology.

(A)

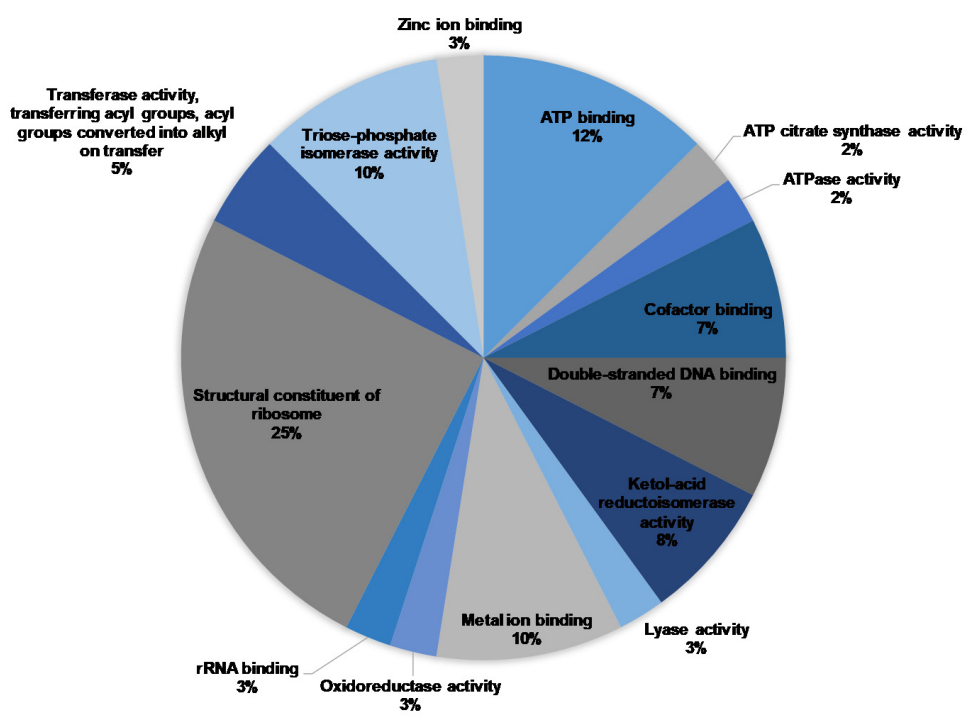

(B)

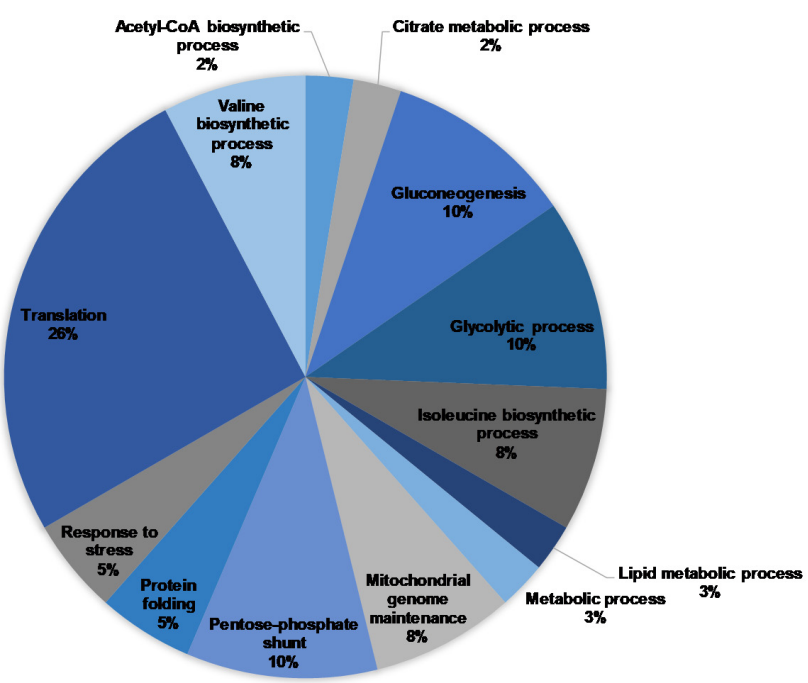

Figure 6. Classification of the differentially expressed proteins identified from L. betulina. Pie charts of the distribution of molecular function (A) and biological process (B). 
ATPases are found in prokaryotes as well as in many eukaryotic plasma membranes and play a vital role in the transport of ions and phospholipids across the membrane [24]. Many studies have reported that gallate derivatives interact with microbial cell membranes, but how these compounds perturb cell membranes remains uncertain [25]. In the present study, the proteins related to ATP binding and ATPase activity were also downregulated, suggesting that the OG enters periplasm and inhibits transmembrane ATPase activity and further reduces the ATP level. While $\mathrm{H}^{+}$-ATPase is the most abundant plasma membrane protein, constituting over $20 \%$ of the total membrane protein in Saccharomyces cerevisiae, the conformation of the protein may be changed by OG, and the plasma membrane may lose its functioning conformations [11]. Moreover, mitochondrial oxidative phosphorylation was also required for ATP generation. Under normal conditions, protons return to the mitochondrial matrix through the $\mathrm{F}_{0}$ proton channel following the concentration gradient. However, adenosine diphosphate (ADP) was phosphorylated to generate ATP in the $\mathrm{F}_{1}$ domain of ATP synthase [26]. Therefore, OG not only caused mitochondrial dysfunction, which reduced the efficiency of energy-dependent processes, such as cell defenses against stress, but also prevented protons from returning to the mitochondrial matrix, leading to endogenous ROS generation.

Additionally, ATP citrate synthase and ATP citrate lyase isoform 2 related to ATP citrate synthase activity were downregulated with the increase in ketol-acid reductoisomerase and triosephosphate isomerase. In other words, OG may remodel the energy metabolism of L. betulina by lowering ATP levels and increasing glycolytic activity to compensate for the downregulation of aerobic pathways. Moreover, decreased efficiency of mitochondrial respiration in fluconazole-resistant strains reduces the ability of endogenous ROS to protect cells from being insulted by antifungal agents, ultimately reducing the resistance to fluconazole [26]. Thus, L. betulina may downregulate Krebs cycle (tricarboxylic acid cycle) activity to minimize the damage caused by endogenous ROS.

Ribosomal proteins play a vital role in monitoring and responding to cellular stress. After exposure to extracellular or intracellular stress, cells rapidly downregulate ribosomal RNA synthesis [27]. Additionally, the regulation of mRNA translation is an evolutionarily conserved mechanism for modulating longevity [28]. However, decreasing the abundance of 605 ribosomal subunits leads to increased replicative lifespan through the deletion of 60S-specific ribosomal processing factors or by the induction of endoplasmic reticulum stress [29]. In the present study, by regulating the cellular response to endoplasmic reticulum stress, L. betulina depleted $60 \mathrm{~S}$ ribosomal subunits, thereby reducing the mycelial growth rate.

Heat shock proteins are highly conserved from bacteria to animals and function as molecular chaperones against stress by inhibiting denatured protein aggregation, helping damaged proteins to fold, or dissolving the denatured proteins [30]. Heat shock protein 90 is achieved by an inducible nitrogen-dependent promoter and causes decreased spore viability, decreased hyphal growth, and severe concomitant defects in germination and conidiation [31]. In this study, heat shock proteins 90 and 90 -alpha were downregulated by OG, which may be a result of stress-responsive expression. Similar fungal responses have been reported with the addition of aromatic hydrocarbons [32].

However, as shown in Figure 7, in T. versicolor, OG downregulated proteins related to protein folding and the aerobic glycerol catabolic, carbohydrate metabolic, glycolytic, metabolic, and misfolded or incompletely synthesized protein catabolic processes and upregulated those related to the $\mathrm{D}_{\mathrm{D}}$-gluconate metabolic process and translation. The trend of proteomics analysis in T. versicolor was similar to that in L. betulina, but the details are more complicated. 

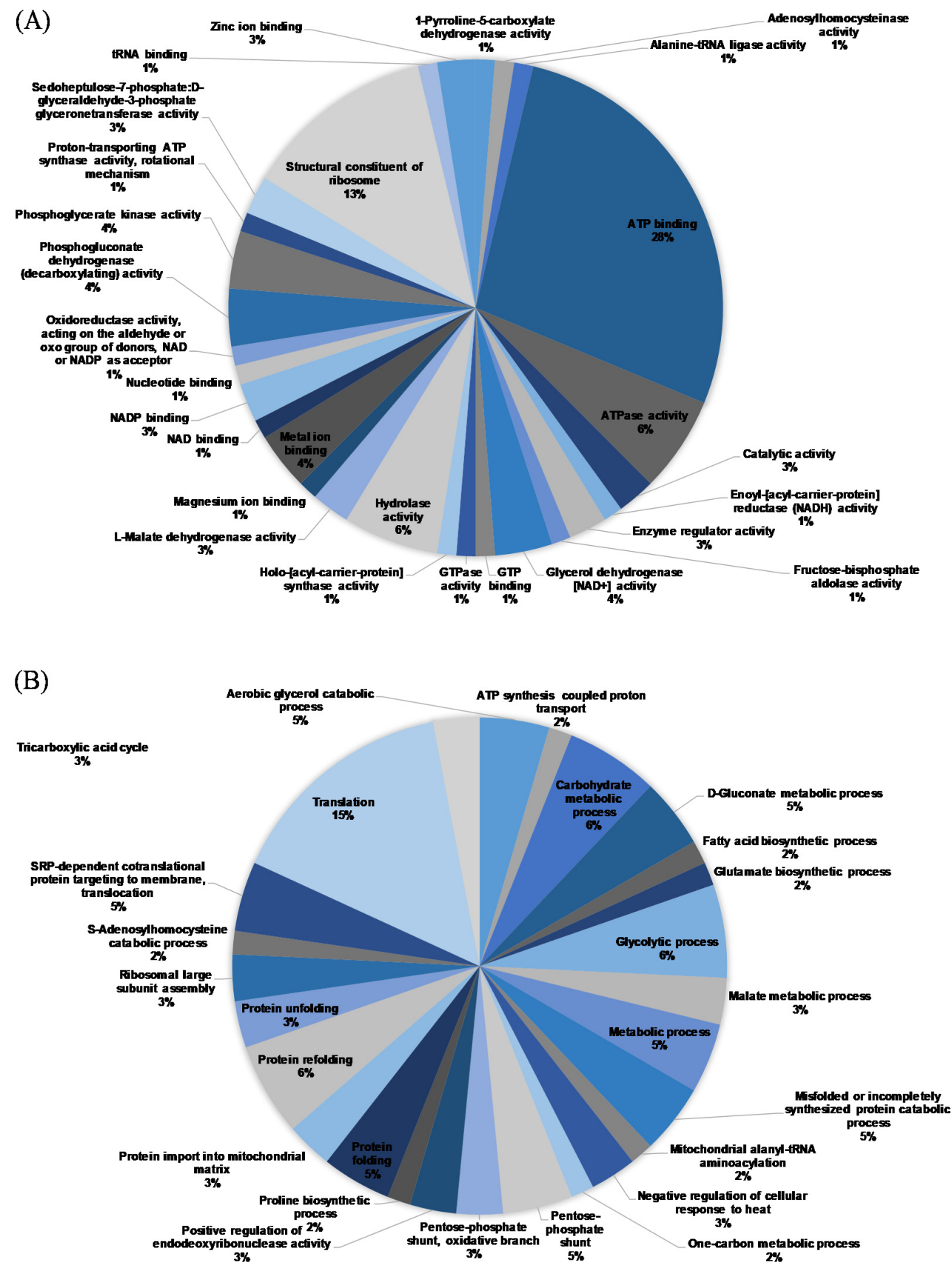

Figure 7. Classification of the differentially expressed proteins identified from T. versicolor. Pie charts of the distribution of molecular functions (A) and biological processes (B).

Similar to L. betulina, the proteins related to ATP binding and ATPase activity were also downregulated by OG, indicating that plasma membrane proteins may have been disrupted. However, glycerol dehydrogenase, malate dehydrogenase, phosphoglycerate kinase, and transaldolase were downregulated, whereas 6-phosphogluconate dehydrogenase was upregulated. This observation indicates the metabolic flux is redirected from glycolysis to the oxidative branch of the pentose phosphate pathway. The pentose phosphate pathway generates nicotinamide adenine dinucleotide phosphate (NADPH), a reducing agent [33]. $\mathrm{NADPH}$ serves as a cofactor for fatty acid synthesis and the recycling steps within the glutathione, thioredoxin, and peroxiredoxin systems, whose redox state control is crucial [34]. Overexpression of transaldolase reduces glucose 6-phosphate dehydrogenase and 6-phosphogluconate dehydrogenase activities, thus reducing NADPH and glutathione 
production and increasing oxidative stress. Suppression of transaldolase results in the opposite effects [35].

However, $60 \mathrm{~S}$ ribosomal proteins of $T$. versicolor were also downregulated by OG, and $40 \mathrm{~S}$ ribosomal proteins were upregulated. The results revealed that the $40 \mathrm{~S}$ preinitiation complexes accumulated in half-mer polyribosomes in the absence of sufficient 605 subunits [36]. Moreover, similar to L. betulina, heat shock protein 70 and proteins related to actin were also downregulated in T. versicolor by OG. Unlike heat shock protein 90, heat shock protein 70 refolds and maintains denatured proteins in vitro, but it also has antiapoptotic activity [37].

Thus, proteomic analysis revealed that OG may act similarly to surfactants by inhibiting ATPase activity, leading to mitochondrial dysfunction and endogenous ROS production. However, after OG treatment, there was no significant difference in the proteins related to laccase and MnP. After exposure to endogenous ROS, cells rapidly downregulated the synthesis of 605 ribosomal subunits, leading to an increased replicative lifespan, thereby reducing the mycelial growth rate. Additionally, L. betulina and T. versicolor also remodeled their energy metabolism in response to low ATP levels and endogenous ROS. In L. betulina, the ATP citrate synthase activity was downregulated and glycolytic activity was upregulated in response to low ATP levels. However, T. versicolor not only reduced its aerobic pathway activity but also upregulated 6-phosphogluconate dehydrogenase and transaldolase, resulting in NADPH generation to minimize the damage from endogenous ROS.

\section{Conclusions}

To develop effective and environmentally friendly wood preservatives, this study investigated the antifungal activity and mechanism of a series of long-chain alkyl gallates (3,4,5-trihydroxybenzoates) against the white-rot fungi L. betulina and T. versicolor. The results revealed that octyl gallate (OG) had the best antifungal activity, with $\mathrm{EC}_{50}$ values of $74.65 \mu \mathrm{g} / \mathrm{mL}$ (L. betulina) and $95.80 \mu \mathrm{g} / \mathrm{mL}$ (T. versicolor). Unexpectedly, however, the activity of laccase and $\mathrm{MnP}$ in T. versicolor was upregulated with the addition of OG. To understand how white-rot fungi respond to OG, we conducted proteomics analysis to identify the changes in proteins. We found that OG impeded the metabolic flexibility of L. betulina and T. versicolor. After OG treatment, ATP citrate synthase activity was downregulated and glycolytic activity was upregulated in L. betulina, while T. versicolor not only reduced aerobic pathway activity but also redirected the pathway to the oxidative branch of the pentose phosphate pathway. Furthermore, OG may inhibit ATPase activity, causing mitochondrial dysfunction and endogenous ROS production. Endogenous ROS also caused ATP-dependent protein (heat shock proteins and 60S ribosomal protein) folding to function suboptimally, leading to membrane damage. Therefore, OG can be a potent inhibitor of white-rot fungi, although further structural optimization and pharmacological investigations are warranted.

Author Contributions: Conceptualization, J.-W.X., Y.-T.T., and J.-H.W.; data curation, J.-W.X. and K.-C.H.; investigation, J.-W.X., C.-C.L., K.-C.H., and Z.-Y.W.; methodology, J.-W.X., Y.-T.T. and J.-H.W.; resources, Y.-T.T. and J.-H.W.; software, J.-W.X. and C.-C.L.; visualization, J.-W.X.; supervision, C.-C.L., Y.-T.T., and J.-H.W.; writing-original draft, J.-W.X.; writing—review and editing, Y.-T.T. and J.-H.W. All authors have read and agreed to the published version of the manuscript.

Funding: This research was funded by a research grant from the Ministry of Science Technology, Taiwan (MOST 105-2815-C-005-024-B and MOST 108-2313-B-005-023-MY3).

Institutional Review Board Statement: Not applicable.

Informed Consent Statement: Not applicable.

Data Availability Statement: The data that support this study are available from the corresponding author upon reasonable request.

Conflicts of Interest: The authors have no conflicts of interest to declare. 


\section{References}

1. Hassan, E.B.; El-Giar, E.M.; Steele, P. Evaluation of the antioxidant activities of different bio-oils and their phenolic distilled fractions for wood preservation. Int. Biodeterior. Biodegrad. 2016, 110, 121-128. [CrossRef]

2. Goodell, B.; Nicholas, D.D.; Schultz, T.P. Introduction to wood deterioration and preservation. In Wood Deterioration and Preservation: Advances in Our Changing World; Goodell, B., Nicholas, D.D., Schultz, T.P., Eds.; American Chemical Society: Washington, DC, USA, 2003; pp. 2-9.

3. Barbero-López, A.; Monzó-Beltrán, J.; Virjamo, V.; Akkanen, J.; Haapala, A. Revalorization of coffee silverskin as a potential feedstock for antifungal chemicals in wood preservation. Int. Biodeterior. Biodegrad. 2020, 152, 105011. [CrossRef]

4. Lourençon, T.V.; Mattos, B.D.; Cademartori, P.H.; Magalhães, W.L. Bio-oil from a fast pyrolysis pilot plant as antifungal and hydrophobic agent for wood preservation. J. Anal. Appl. Pyrolysis 2016, 122, 1-6. [CrossRef]

5. Yalcin, M.; Akcay, C.; Sahin, H.I. The effect of particle board industry waste tar on the physical and biological durability of wood. Bioresources 2020, 15, 1810-1827. [CrossRef]

6. Valette, N.; Perrot, T.; Sormani, R.; Gelhaye, E.; Morel-Rouhier, M. Antifungal activities of wood extractives. Fungal Biol. Rev. 2017, 31, 113-123. [CrossRef]

7. Saibabu, V.; Fatima, Z.; Ahmad, K.; Khan, L.A.; Hameed, S. Octyl gallate triggers dysfunctional mitochondria leading to ROS driven membrane damage and metabolic inflexibility along with attenuated virulence in Candida albicans. Med. Mycol. 2019, 58, 380-392. [CrossRef]

8. Hsu, F.-L.; Chen, P.-S.; Chang, H.-T.; Chang, S.-T. Effects of alkyl chain length of gallates on their antifungal property and potency as an environmentally benign preservative against wood-decay fungi. Int. Biodeterior. Biodegrad. 2009, 63, 543-547. [CrossRef]

9. Zacchino, S.A.; Butassi, E.; Di Liberto, M.; Raimondi, M.; Postigo, A.; Sortino, M. Plant phenolics and terpenoids as adjuvants of antibacterial and antifungal drugs. Phytomedicine 2017, 37, 27-48. [CrossRef]

10. Badhani, B.; Sharma, N.; Kakkar, R. Gallic acid: A versatile antioxidant with promising therapeutic and industrial applications. RSC Adv. 2015, 5, 27540-27557. [CrossRef]

11. Kubo, I.; Xiao, P.; Fujita, K. Antifungal activity of octyl gallate: Structural criteria and mode of action. Bioorg. Med. Chem. Lett. 2001, 11, 347-350. [CrossRef]

12. Kubo, I.; Fujita, K.-I.; Nihei, K.-I. Anti-SalmonellaActivity of Alkyl Gallatest. J. Agric. Food Chem. 2002, 50, 6692-6696. [CrossRef]

13. Lin, C.-Y.; Lin, L.-C.; Ho, S.-T.; Tung, Y.-T.; Tseng, Y.-H.; Wu, J.-H. Antioxidant Activities and Phytochemicals of Leaf Extracts from 10 NativeRhododendronSpecies in Taiwan. Evid. Based Complement. Altern. Med. 2014, 2014, 1-9. [CrossRef]

14. Tamagawa, Y.; Yamaki, R.; Hirai, H.; Kawai, S.; Nishida, T. Removal of estrogenic activity of natural steroidal hormone estrone by ligninolytic enzymes from white rot fungi. Chemosphere 2006, 65, 97-101. [CrossRef]

15. Liao, C.-C.; Chiu, Y.-S.; Chiu, W.-C.; Tung, Y.-T.; Chuang, H.-L.; Wu, J.-H.; Huang, C.-C. Proteomics Analysis to Identify and Characterize the Molecular Signatures of Hepatic Steatosis in Ovariectomized Rats as a Model of Postmenopausal Status. Nutrients 2015, 7, 8752-8766. [CrossRef]

16. Liao, C.-C.; Chen, Y.-W.; Jeng, T.-L.; Li, C.-R.; Kuo, C.-F. Consumption of Purple Sweet Potato Affects Post-Translational Modification of Plasma Proteins in Hamsters. J. Agric. Food Chem. 2013, 61, 12450-12458. [CrossRef]

17. Uen, Y.H.; Lin, K.Y.; Sun, D.P.; Liao, C.C.; Hsieh, M.S.; Huang, Y.K.; Chen, Y.W.; Huang, P.H.; Chen, W.J.; Tai, C.C.; et al. Comparative proteomics, network analysis and post-translational modification identification reveal differential profiles of plasma Con A-bound glycoprotein biomarkers in gastric cancer. J. Proteomics 2013, 83, 197-213. [CrossRef] [PubMed]

18. Andjelkovic, M.; Vancamp, J.; Demeulenaer, B.; Depaemelaere, G.; Socaciu, C.; Verloo, M.; Verhe, R. Iron-chelation properties of phenolic acids bearing catechol and galloyl groups. Food Chem. 2006, 98, 23-31. [CrossRef]

19. Sergentani, A.G.; Gonou-Zagou, Z.; Kapsanaki-Gotsi, E.; Hatzinikolaou, D.G. Lignocellulose degradation potential of Basidiomycota from Thrace (NE Greece). Int. Biodeterior. Biodegrad. 2016, 114, 268-277. [CrossRef]

20. Alberts, J.; Gelderblom, W.; Botha, A.; Van Zyl, W. Degradation of aflatoxin B1 by fungal laccase enzymes. Int. J. Food Microbiol. 2009, 135, 47-52. [CrossRef] [PubMed]

21. Tortella, G.R.; Rubilar, O.; Gianfreda, L.; Valenzuela, E.; Diez, M.C. Enzymatic characterization of Chilean native wood-rotting fungi for potential use in the bioremediation of polluted environments with chlorophenols. World J. Microbiol. Biotechnol. 2008, 24, 2805-2818. [CrossRef]

22. Piscitelli, A.; Giardina, P.; Lettera, V.; Pezzella, C.; Sannia, G.; Faraco, V. Induction and Transcriptional Regulation of Laccases in Fungi. Curr. Genom. 2011, 12, 104-112. [CrossRef] [PubMed]

23. Jaszek, M.; Grzywnowicz, K.; Malarczyk, E.; Leonowicz, A. Enhanced extracellular laccase activity as a part of the response system of white rot fungi: Trametes versicolor and Abortiporus biennis to paraquat-caused oxidative stress conditions. Pestic. Biochem. Physiol. 2006, 85, 147-154. [CrossRef]

24. Sant, D.; Tupe, S.; Ramana, C.; Deshpande, M. Fungal cell membrane-promising drug target for antifungal therapy. J. Appl. Microbiol. 2016, 121, 1498-1510. [CrossRef]

25. Takai, E.; Hirano, A.; Shiraki, K. Effects of alkyl chain length of gallate on self-association and membrane binding. J. Biochem. 2011, 150, 165-171. [CrossRef]

26. Xu, Y.; Wang, Y.; Yan, L.; Liang, R.-M.; Dai, B.-D.; Tang, R.-J.; Gao, P.-H.; Jiang, Y.-Y. Proteomic Analysis Reveals a Synergistic Mechanism of Fluconazole and Berberine against Fluconazole-ResistantCandida albicans: Endogenous ROS Augmentation. J. Proteome Res. 2009, 8, 5296-5304. [CrossRef] [PubMed] 
27. Mayer, C.; Grummt, I. Cellular Stress and Nucleolar Function. Cell Cycle 2005, 4, 1036-1038. [CrossRef] [PubMed]

28. Mehta, R.; Chandler-Brown, D.; Ramos, F.J.; Shamieh, L.S.; Kaeberlein, M. Regulation of mRNA Translation as a Conserved Mechanism of Longevity Control. Adv. Exp. Med. Biol. 2010, 694, 14-29. [CrossRef] [PubMed]

29. Steffen, K.K.; MacKay, V.L.; Kerr, E.O.; Tsuchiya, M.; Hu, D.; Fox, L.A.; Dang, N.; Johnston, E.D.; Oakes, J.A.; Tchao, B.N.; et al. Yeast Life Span Extension by Depletion of 60S Ribosomal Subunits Is Mediated by Gcn4. Cell 2008, 133, 292-302. [CrossRef]

30. Zhang, X.; Ren, A.; Li, M.-J.; Cao, P.-F.; Chen, T.-X.; Zhang, G.; Shi, L.; Jiang, A.-L.; Zhao, M.-W. Heat Stress Modulates Mycelium Growth, Heat Shock Protein Expression, Ganoderic Acid Biosynthesis, and Hyphal Branching of Ganoderma lucidum via Cytosolic Ca2+. Appl. Environ. Microbiol. 2016, 82, 4112-4125. [CrossRef] [PubMed]

31. Lamoth, F.; Juvvadi, P.R.; Fortwendel, J.R.; Steinbach, W.J. Heat Shock Protein 90 Is Required for Conidiation and Cell Wall Integrity in Aspergillus fumigatus. Eukaryot. Cell 2012, 11, 1324-1332. [CrossRef]

32. Bedin, M.; Gaben, A.-M.; Mester, J. Geldanamycin, an inhibitor of the chaperone activity of HSP90, induces MAPK-independent cell cycle arrest. Int. J. Cancer 2004, 109, 643-652. [CrossRef]

33. Grant, C.M. Metabolic reconfiguration is a regulated response to oxidative stress. J. Biol. 2008, 7, 1-4. [CrossRef] [PubMed]

34. Grüning, N.M.; Rinnerthaler, M.; Bluemlein, K.; Mülleder, M.; Wamelink, M.M.C.; Lehrach, H.; Jakobs, C.; Breitenbach, M.; Ralser, M. Pyruvate kinase triggers a metabolic feedback loop that controls redox metabolism in respiring cells. Cell Metab. 2011, 14, 415-427. [CrossRef] [PubMed]

35. Perl, A.; Hanczko, R.; Telarico, T.; Oaks, Z.; Landas, S. Oxidative stress, inflammation and carcinogenesis are controlled through the pentose phosphate pathway by transaldolase. Trends Mol. Med. 2011, 17, 395-403. [CrossRef] [PubMed]

36. Rotenberg, M.; Moritz, M.; Woolford, J.L. Depletion of Saccharomyces cerevisiae ribosomal protein L16 causes a decrease in 605 ribosomal subunits and formation of half-mer polyribosomes. Genes Dev. 1988, 2, 160-172. [CrossRef]

37. Jolly, C. Role of the Heat Shock Response and Molecular Chaperones in Oncogenesis and Cell Death. J. Natl. Cancer Inst. 2000, 92, 1564-1572. [CrossRef] 